УДК: 351.82:332.3

https://doi.org/10.52058/2708-7530-2021-12(18)-147-159

Неймарк Ольга Аліївна аспірантка кафедр глобальної та національно безпеки НHI Публічного управління та державної служби, КНУ імені Тараса Шевченка, вул. Антона Цедіка, 20, м. Київ, 03057, тел.: (095) 331-30-08, e-mail: bilotserkivska.o@gmail.com, https://orcid.org/0000-0002-2149-9125

\title{
ГРОМАДЯНСЬКЕ СУСПІЛЬСТВО ЯК ЧИННИК ЗАБЕЗПЕЧЕННЯ ГУМАНІТАРНОЇ БЕЗПЕКИ
}

Анотація. У статті досліджені особливості становлення громадянського суспільства в контексті забезпечення гуманітарної безпеки як складової національної безпеки. Зазначено, що в науковій думці виділяють два ключові підходи до розуміння сутності громадянського суспільства. В рамках першого останнє розглядається як певна соціальна універсалія, як сукупність суспільних відносин, що протиставляються державі в будь-якій іiі формі, тобто все, що не державним, а в рамках другого підходу громадянське суспільство розглядається як конкретний феномен, як певна форма існування розвинутого демократичного суспільства. Підкреслюється, що інститути громадянського суспільства беруть активну участь у розробці вітчизняної гуманітарної політики, зокрема в сфері освіти, культури, історичної пам'яті тощо.

Акцентується увага на тому, що у цивілізованій державі громадські організації створюють потужний зворотний зв'язок, який сприяє оздоровленню державного організму i $\epsilon$ стимулятором прогресу. Вказується, що конструктивна функція громадських організацій напряму пов'язана 3 їхньою незалежністю, а в ряді випадків, - і прямої опозиції державі. Спроби заміни незалежних громадських організацій на квазідержавні громадські утворення, як це відбувалося в колишньому СРСР чи спостерігається сьогодні в деяких країнах пострадянського простору, зокрема тій же Росії, неминуче приводять до серйозної деформації демократичного політичного режиму суспільства. Зазначається, що внутрішньополітична стабільність в державі, подолання зовнішніх загроз та викликів потребують суттєвого вдосконалення системи зворотного зв'язку між владою та суспільством.

Підкреслюється, що формування ефективної політики національної безпеки передбачає розвиток дієвого громадянського суспільства, яке може здійснювати ефективний громадський контроль над системою національної безпеки країни. Сама ідея громадського контролю в сфері національної безпеки $\epsilon$ важливим показником демократизації держави та суспільства в цілому. Вказується, що недержавні організації, створені з метою дослідження проблем безпеки та оборони, виконують ключову функцію в системі взаємодії 
громадянського суспільства зі структурами сектору безпеки - фаховий моніторинг стану, проблем та перспектив як системи забезпечення національної безпеки в цілому, так і iї окремих складових.

Ключові солова: громадянське суспільство, національна безпека, гуманітарна безпека, сектор безпеки та оборони.

Neymark Olga Aliyivna Graduate student of the Departments of Global and National Security, Institute of Public Administration and Civil Service, Taras Shevchenko National University, Anton Tsedik St., 20, Kyiv, 03057, tel.: (095) 331-30- 08, e-mail: bilotserkivska.o@gmail.com, https://orcid.org/00000002-2149-9125

\title{
CIVIL SOCIETY AS A FACTOR IN ENSURING HUMANITARIAN SECURITY
}

\begin{abstract}
The article examines the peculiarities of the formation of civil society in the context of humanitarian security as a component of national security. It is noted that in scientific thought there are two key approaches to understanding the essence of civil society. In the first, the latter is seen as a certain social universal, as a set of social relations opposed to the state in any form, ie everything that is not state, and in the second approach, civil society is seen as a specific phenomenon, as a form of developed democratic society. It is emphasized that civil society institutions are actively involved in the development of domestic humanitarian policy, in particular in the field of education, culture, historical memory, etc.

Emphasis is placed on the fact that in a civilized state, public organizations create a powerful feedback that promotes the health of the state body and is a stimulator of progress. It is pointed out that the constructive function of public organizations is directly related to their independence, and in some cases, to direct opposition to the state. Attempts to replace independent non-governmental organizations with quasi-state non-governmental organizations, as was the case in the former USSR or observed today in some post-Soviet countries, including Russia, inevitably lead to a serious deformation of the democratic political regime. It is noted that internal political stability in the country, overcoming external threats and challenges require significant improvement of the feedback system between the government and society.

It is emphasized that the formation of an effective national security policy involves the development of an effective civil society that can exercise effective public control over the national security system of the country. The very idea of public control in the field of national security is an important indicator of the democratization of the state and society as a whole. It is pointed out that nongovernmental organizations established to study security and defense issues play a key function in the system of interaction of civil society with structures of the
\end{abstract}


security sector - professional monitoring of the state, problems and prospects of the national security system as a whole and its individual components.

Keywords: civil society, national security, humanitarian security.

Постановка проблеми. Однією 3 ключових умов реалізації політики національної безпеки, зокрема й в гуманітарній галузі, $є$ запровадження ефективного й системного громадського контролю за іiі реалізацією. У Законі України "Про національну безпеку України" розвиток громадянського суспільства, його демократичних інститутів проголошено одним 3 пріоритетів національних інтересів України.

За всіх часів люди прагнули сформувати ідеальну державу, де владні структури зразково б виконували свої функції, покращуючи добробут i забезпечуючи безпеку населення, а прості громадяни могли впливати на владу.

Сьогодні людство досягло прогресу в багатьох галузях, зокрема й в сфері формування громадянського суспільства, яке стає важливим посередником між громадянами та державою. В сучасних умовах підтримка громадянського суспільства та становлення правової держави $є$ одними 3 головних чинників забезпечення іiі національної безпеки, оскільки в повній мірі свої свободи громадяни країни можуть захистити тільки в розвинутій правовій державі, а інститути правової держави не зможуть ефективно працювати без підтримки громадянського суспільства.

Аналіз останніх досліджень і публікацій. Серед авторів, що займалися науковим дослідження проблематики національної безпека та місця у неї гуманітарної безпеки можна виділити таких вчених, як В. Горбулін, С. Здіорук, О. Литвиненко, А. Качинський, Г. Новицький, С. Кісєльов, М. Розумний, Б. Парахонський, С. Пірожков, Г. Ситник, Л.Чупрій, М. Ожеван, Ю. Опалько, М.Баюк та ін. У роботах цих авторів зазначається, що громадянське суспільство $\epsilon$ одним з важливих чинників забезпечення національної безпеки.

Мета статті - дослідити особливості розвитку громадянського суспільства в контексті забезпечення гуманітарної безпеки як складової національної безпеки.

Виклад основного матеріалу. В сучасній науковій думці виділяють два ключові підходи до розуміння сутності громадянського суспільства. В рамках першого останнє розглядається як певна соціальна універсалія, як сукупність суспільних відносин, що протиставляються державі в будь-якій їі формі, тобто все, що не державним. В рамках другого підходу громадянське суспільство розглядається як конкретний феномен, як певна форма існування розвинутого демократичного суспільства i його виникнення пов'язане 3 становленням громадянина, який має власні свободи, права і обов'язки.

Сьогодні громадянське суспільство визначається здебільшого як система самостійних i незалежних від держави громадянських структур i міжособистісних відносин, які забезпечують належні умови для розвитку i

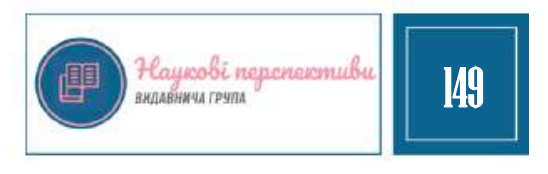


самореалізації індивідів та окремих соціальних груп в політичній, соціальній, правовій, економічній, культурній та інших суспільних сферах. Це також колектив активних особистостей, які мають високий рівень громадської активності і сформовані людські якості (моральність, повагу до інших, відповідальність, прагнення до самовдосконалення) і здатні належним чином захищати свої інтереси.

Слід констатувати, що саме громадянське суспільство активно впливає на розвиток правової держави, оскільки відповідний правовий порядок може існувати там, де суспільство незалежно від держави має i може використовувати засоби і санкції, що будуть спонукати окремого індивіда виконувати загальноприйняті моральні норми. Саме інститути громадянського суспільства (родина, релігійні організації, соціальні групи, добровільні об'єднання та спілки) здатні виконувати подібну роль. І. Кант досліджував дане явище, називаючи це «моральною автономією». У випадку, коли структури громадянського суспільства не здатні забезпечити належний рівень дотримання в суспільстві моральних норм, то цю функцію бере на себе держава, зокрема іiі правоохоронні органи, а це може призвести до підміни суспільної безпеки безпекою держави. Якщо держава стає регулятором суспільної моралі, то вона проникає у внутрішній світ людини, обмежує чи порушує їі права і свободи, а отже перетворюється в авторитарну чи навіть тоталітарну державу.

Якщо громадянське суспільство в країні не розвивається, то для забезпечення порядку та стабільності, держава досить часто застосовує жорсткі чи навіть репресивні методи. При слабкому громадянському суспільстві, громадські структури не приймають належної участі у формуванні засад зовнішньополітичної та внутрішньополітичної діяльності, забезпеченні національної безпеки. Цим займаються різні гілки влади та квазігромадські структури, які залежать від влади та працюють на неї і досить часто мають різноспрямовані інтереси, що посилює конфлікти між ними і призводить до зниження ефективності функціонування державних інституцій, порушення законності і правопорядку, зростання злочинності та корупції, посилення соціальної нестабільності, виникнення конфліктів на релігійно-конфесійній, культурно-етнічній і регіональних основах.

Крім того, в умовах недостатнього рівня розвитку громадянського суспільства, серед представників політичної еліти виникає тенденція до підміни основоположних понять національної безпеки питаннями захисту безпеки політичного режиму і збереження влади. Відтак відбувається підміна і безпека держави починає тлумачитися як захист корпоративних інтересів та прагнень можновладних структур, правлячих еліт, певних кланів, олігархічних груп тощо, інтереси яких починають видаватися за ключові національні інтереси держави i суспільства в цілому. В цих умовах діяльність спецслужб, правоохоронних органів, ЗМІ буде спрямована на збереження панівного становища правлячої еліти та олігархічних груп, ЗМІ поширюватимуть 
дезінформацію, що сприятиме посиленню контролю над суспільством, що ми й спостерігаємо сьогодні в Російській Федерації.

Відтак потрібно чітко вказувати, що система національної безпеки в правовій державі 3 демократичними цінностями повинна обов'язково передбачати наявність розвинутих громадських інституцій як повноправного суб'єкта відносин, оскільки сфера безпеки не може бути тільки монополією держави. Відносини державних i недержавних (громадянських) структур повинні базуватися на принципах взаємодії та відкритості. В результаті їхної взаємодіючої і взаємообмежуючої діяльності формується і зміцнюється нова системна якість, досягається баланс інтересів людини, суспільства, держави та достатньо високий рівень прозорості та відсутності загроз правам і свободам людини й універсальним базовим інтересам і цінностям держави та суспільства

В Конституції України зазначається, що Україна є демократичною соціальною, правовою державою і що носієм суверенітету i єдиним джерелом влади в Україні є народ. Відтак громадяни України мають право брати участь у виборах, референдумах та інших формах безпосередньої демократії, відповідно вони формують виборні органи влади та органи місцевого самоврядування, забезпечують реалізацію національних інтересів і через об'єднання громадян доносять до уваги суспільних і державних інститутів інформацію про небезпечні явища і процеси у різних сферах життєдіяльності країни. Громадяни також мають право у законний спосіб захищати власні права та інтереси, а також особисту безпеку. Активна діяльність інститутів громадянського суспільства сприятиме зміцненню гарантій додержання законності, прав і свобод людини та громадянина, забезпеченню адекватності системи національної безпеки загрозам національним інтересам та економічним можливостям держави.

У цивілізованій державі громадські організації створюють потужний зворотний зв'язок, який сприяє оздоровленню державного організму i $\epsilon$ стимулятором прогресу. Конструктивна функція громадських організацій напряму пов'язана 3 їхньою незалежністю, а в ряді випадків, - i прямою опозицією державі. Спроби заміни незалежних громадських організацій на квазідержавні громадські утворення, як це відбувалося в колишньому СРСР чи спостерігається сьогодні в деяких країнах пострадянського простору, зокрема тій же Росії, неминуче приводять до серйозної деформації демократичного політичного режиму суспільства. Отже внутрішньополітична стабільність в державі, подолання зовнішніх загроз та викликів потребують суттєвого вдосконалення системи зворотного зв’язку між владою та суспільством. Саме діяльність та контроль громадянських організацій слугує запобіжником „сповзання” держави до авторитаризму чи хаосу та безвладдя. Інститути громадянського суспільства покликані захищати інтереси суспільства в наступних взаємопов'язаних площинах:

- Діяльність інститутів державної влади, що забезпечують територіальну цілісність, конституційний лад, суверенітет, сталий розвиток держави; 
- Визначення ключових орієнтирів зовнішньої політики, вироблення механізмів протидії зовнішнім загрозам національній безпеці держави та суспільства, захист прав громадян України за кордоном;

- Захист та реалізація конституційних прав i свобод людини й громадянина.

Аналізуючи стан розвитку громадянського суспільства в Україні, слід зазначити, що на сьогодні в Україні діяльність громадських організацій визначається такими нормативно-правовими документами: "Про громадські об'єднання (2012р.), “ Про основні засади молодіжної політики» (2021р.), “Про благодійну діяльність та благодійні організації” (2012р.), “Про професійних творчих працівників та творчі спілки” (1997р.), “Про професійні спілки, їх права та гарантії діяльності" (1999р.), "Про організації роботодавців, їх об'єднання, права і гарантії їх діяльності " (2012), "Про асоціації органів місцевого самоврядування" та інші акти законодавства.

Аналізуючи кількісні характеристики, слід зазначити, що на сьогодні органами юстиції в Україні легалізовано/зареєстровано близько 50 тис. громадських формувань, із яких 66 \% становлять місцеві, всеукраїнські та міжнародні громадські організації, 0,3% політичні партії, 31 \% місцеві, всеукраїнські, та міжнародні благодійні організації [1].

Щодо професійної спрямованості громадських організацій то серед них можна виділити: фізкультурні (18\%), професійні (15\%), молодіжні (11\%), ветеранів та інвалідів (9\%), культурні та просвітницькі (7\%), етнонаціональні $(5 \%)$, захисту прав людини (5\%) [1].

Хоча в цілому в нас нараховується велика кількість громадських організацій проте тільки невелика частина українців беруть участь у їхній діяльності. Так за даними результатів соціологічних досліджень, проведених Інститутом соціології НАН України, 80 \% громадян України не є членами жодної з громадських організацій. Подібне опитування Фонду «Демократичні ініціативи» імені Ілька Кучеріва та соціологічної служби Центру Разумкова, показало, 86 \% мешканців України не входять до складу жодних громадських організацій чи об'єднань. Хоча загалом кількість громадських організацій в Україні майже не поступається середньоєвропейському рівню.

Щодо гуманітарної галузі, то близько 7 \% громадських організацій здійснюють діяльність у сфері культури, освіти, просвітницької діяльності. Інститути громадянського суспільства беруть активну участь у розробці гуманітарної політики. Так в законі Про культуру від 14.12.2010 № 2778-VI1[2] в статті 31 зазначається, що громадські організації беруть участь у реалізації державної політики у сфері культури відповідно до законодавства. Інститути громадянського суспільства мають право самостійно та на договірній основі утворювати благодійні організації для фінансування культурних програм розвитку літератури та мистецтва, підтримки талантів i творчих починань у сфері культури, розв'язання соціальних і побутових проблем професійних 
творчих працівників[2].

Відповідно до статті 71 Закону України «Про освіту» [3], громадські організації, установчими документами яких передбачено діяльність у сфері освіти, мають право здійснювати громадський нагляд (контроль) у системі освіти.

Зокрема суб’єкти громадського нагляду (контролю) мають право:

1) ініціювати і проводити дослідження з питань освіти та популяризувати результати таких досліджень;

2) проводити моніторинг та висвітлювати результати якості навчання, якості підручників та інших навчальних матеріалів інше;

3) брати участь у публічному обговоренні різноманітних аспектів освітнього процесу [3].

Щодо галузі національної безпеки, то громадянські організації сприяють розвитку громадянського суспільства i досягненню внутрішньополітичної стабільності. Серед недержавних структур, які беруть участь у розробці політики національної безпеки, слід виділити науково-дослідні та аналітичні організації, які досліджують питаннями реформування та взаємодії влади i громадянського суспільства, зокрема і в сфері безпеки та оборони. Це Центр Разумкова, Інститут майбутнього, КМIC, Український незалежний центр політичних досліджень, коаліція «Реанімаційний пакет Реформ», Інститут стратегічних досліджень «Нова Україна», Центр досліджень армії, роззброєння і конверсії, Центр розвитку інновацій Києво-Могилянської Академї, ГО «Демократичні ініціативи», FinMaidan, ініціатива «Спільно», Центр «Борисфер-Інтел», Асоціація сприяння самоорганізації населення, проект «Нова країна», Антикорупційний Майдан та інші .

Суспільство має активно залучатися до здійснення громадянського контролю над національною безпекою як в зовнішній так і внутрішній сфері держави. Повинен відбуватися контроль над функціонуванням силових структур України. Громадські недержавні структури мають приймати активну участь при вирішенні таких актуальних для країни питань, як контроль над ефективністю роботи органів виконавчої влади, розвиток демократичних процесів, корумпованість, боргова залежність, антикризові заходи, кризові явища в екологічній сфері і безпека життєдіяльності.

Проблему контролю громадських інститутів Г. Мерніков пропонує розглядати у площині двох взаємопов'язаних чинників [4]:

1. Ефективність існуючої системи державного управління в Україні, іiі адекватність новим загрозам суверенітету та територіальній цілісності держави.

2. Ступінь зрілості громадянського суспільства, спроможність громадян України у повному обсязі реалізувати визначені Конституцією повноваження головного джерела влади.

Відтак, формування ефективної політики національної безпеки у внутрішньополітичній сфері передбачає розвиток дієвого громадянського 
суспільства, яке може здійснювати ефективний громадський контроль над системою національної безпеки країни. Сама ідея громадського контролю в сфері національної безпеки є важливим показником демократизації держави та суспільства в цілому. В нашій країні на даний момент тільки починають розроблятися механізми такого контролю та створюється відповідна законодавча база.

У Законі України "Про національну безпеку України» в статті 1 зазначається що, до складу структур сектор безпеки і оборони держави крім відповідних силових, військових та правохоронних структур можуть входити також громадяни та громадські об'єднання, які на добровільних засадах беруть участь у забезпеченні національної безпеки України. В статті 4 третього розділу цього закону зазначається, що сектор безпеки i оборони підлягає демократичному цивільному контролю [5].

Система цивільного контролю складається 3 контролю, що здійснюється Президентом України; контролю, що здійснюється Верховною Радою України; контролю, що здійснюється Радою національної безпеки і оборони України; контролю, що здійснюється Кабінетом Міністрів України, органами виконавчої влади та органами місцевого самоврядування; судового контролю; громадського контролю" [5].

В статті 29 цього закону зазначається, що Міністерство внутрішніх справ повинно розробити Стратегію громадської безпеки та цивільного захисту після затвердження Стратегії національної безпеки України. Стратегію громадської безпеки та цивільного захисту після розробки вноситься на розгляд Кабінету Міністрів України, потім вона направляється до Ради національної безпеки і оборони України та остаточно затверджується указом Президента України.

У розробці проекту Стратегії громадської безпеки та цивільного захисту можуть брати участь як державні органи сектору безпеки та оборони так i наукові, аналітичні та експертні установи України, інститути громадянського суспільства, а також можуть бути залучені іноземні експерти[5].

В даному контексті екс-секретар РНБО України С. Марчук акцентував увагу на важливості створення демократичного контролю над силовими структурами і підкреслював, що для досягнення цієї мети єдиного правильного шляху не існує. Залежно від власного досвіду, стану моральної сфери суспільства, політичного устрою кожна держава має свої особливості у підходах до розбудови механізмів цивільного контролю. Це проявляється через поєднання заходів законодавчого характеру (через законодавчий орган країни) та організаційних заходів (через Кабінет міністрів ) за умови функціонування незалежної i неупередженої судової гілки влади. Щодо специфічних особливостей цивільного контролю у європейських країнах, то вони базується на стійких ціннісних орієнтирах та розвинутій політичній культурі ліберальних демократій [6].

Щодо встановлення демократичного контролю над силовими структурами, 
то Україна на міжнародному рівні зобов'язалася здійснити відповідні кроки, що висвітлено у таких документах: Програма НАТО "Партнерство заради миру: рамковий документ", Кодекс поведінки ОБСС, що стосується воєннополітичних аспектів безпеки, Хартія про особливе партнерство між Україною та НАТО, Плану дій що́до чле́нства в НАТО.

Виконання Україною зобов'язань щодо наближення структур до стандартів Свропейського Союзу в сфері безпеки та впровадження в діяльність силових структур принципів закладених Резолюцією (№ 1402, 1999р.) та Рекомендаціями (№ 1703, 2005 р.) Парламентської асамблеї Ради Європи відповідає корінним загальнонаціональним інтересам:

- розбудові демократичної правової держави;

- якісному вдосконаленню сектору безпеки;

- формуванню необхідних умов функціонування інститутів громадянського суспільства;

- інтеграції до євроатлантичного простору безпеки.

Г. Мерніков наголошує на необхідності розрізняти громадський та громадянський (цивільний) контроль за функціонуванням Системи забезпечення національної безпеки [4].

Цивільний контроль - більш „вузьке”, спеціальне, законодавчо унормоване поняття. Відповідно до положень Закону України „Про демократичний цивільний контроль над Воєнною організацією і правоохоронними органами держави”, «цивільний контроль - комплекс правових, організаційних, інформаційних заходів спрямованих на забезпечення неухильного дотримання законності й відкритості в діяльності всіх структур сектору безпеки та оброни країни, сприяння їхній ефективній діяльності відповідно до вимог вітчизняного законодавства й виконанню покладених на них функцій, зміцненню державної та військової дисципліни» [7].

Громадський контроль реалізуються представниками недержавного сектору. Серед основних недержавних суб'єктів, що можуть здійснювати громадський контроль і захищати інтереси суспільства, можна назвати [7]:

1. Профспілки;

2. Політичні партії та громадські об'єднання;

3. Засоби масової інформації;

4. Судові інстанції різноманітного рівня;

5. Незалежні аналітичні центри й установи та інші неурядові інституції.

Недержавні організації, створені з метою дослідження проблем безпеки та оборони, виконують ключову функцію в системі взаємодії громадянського суспільства зі структурами сектору безпеки - фаховий моніторинг стану, проблем та перспектив як системи забезпечення національної безпеки в цілому, так і їі окремих складових. Ефективність їх діяльності в цій сфері залежить від наступних складових: 
1. Статутна діяльність виключно в межах, визначених Конституцією та законами України, що регламентують особливості режиму захисту інформації.

2. Рівень фахової підготовки, прийнятний стан організаційно-технічного, фінансового забезпечення.

3. Незалежність від органів державної влади.

4. Наявність механізмів залучення до реалізації державної політики у сфері безпеки та оборони.

5. Відсутність прямих чи опосередкованих зв'язків 3 іноземними структурами чи окремими громадянами, діяльність яких загрожує національним інтересам держави [8, с. 42].

Для посилення ролі інститутів громадського суспільства у процесах державного управління слід здійснити комплекс заходів, а саме [8]:

- удосконалення законодавчого забезпечення розвитку громадянського суспільства;

- надання недержавним структурам у повному обсязі інформації про діяльність державних організацій, за винятком тієї, що становить державну таємницю;

- сприяння висвітленню в засобах масової інформації прикладів успішної співпраці органів державної влади 3 інститутами громадянського суспільства;

- створення ефективних механізмів запобігання втручання органів виконавчої влади в діяльність недержавних організацій, за винятком випадків порушення останніми українських законів;

- залучення органами державної влади недержавних організацій до управління різними сферами суспільного життя ".

Слід констатувати, що в Україні поки що залишаються не вирішеними питання ефективного впровадження національного законодавства у сфері цивільного контролю над системою національної безпеки, не чітко визначена роль громадських інституцій у забезпеченні контролю над сектором безпеки. Так у Законі України "Про національну безпеку України» зазначається, що сектор безпеки і оборони підлягає демократичному громадського контролю, зокрема й через громадські організації. Зазначається, що громадські організації можуть отримувати в установленому порядку від державних органів, зокрема від керівників складових сектору безпеки i оборони, інформацію 3 питань діяльності складових сектору безпеки і оборони, але яким саме чином, у які терміни, не зазначається. В Законі також вказується про обов'язкове вироблення Стратегії громадської безпеки та цивільного захисту України, яка визначає загрози національній безпеці у сферах громадської безпеки та цивільного захисту та шляхи досягнення цілей i реалізації пріоритетів державної політики у цих сферах. Але Стратегія національної безпеки вже прийнята, а Стратегії громадської безпеки та цивільного захисту України, так i 
не розроблено, хоча в Законі України "Про національну безпеку України» чітко зазначено, що Стратегія громадської безпеки та цивільного захисту України розробляється відразу після затвердження Стратегії національної безпеки України, що засвідчує недостатній інтерес органів влади до інститутів громадянського суспільства. Відтак до першочергових завдань в сфері покращення цивільного контролю над системою національної безпеки можна віднести: чіткіше законодавче закріплення повноважень та функцій контролю органів державної влади з боку громадянського суспільства; удосконалення базового Закону «"Про національну безпеку України»; напрацювання механізмів залучення інститутів громадянського суспільства до контролю діяльності сектору безпеки; розвиток законодавчої та нормативно-правової бази інституційних основ громадського контролю; проведення суспільного діалогу щодо стратегічних питань національної безпеки; проведення періодичної відкритої звітності вищих посадових осіб держави та їх персональна відповідальність.

За результатами дослідження Левенця С.В. визначені такі перешкоди на шляху на шляху активізації діяльності недержавних організацій у безпековій та інших сферах:

- недосконалість нормативно-правової бази забезпечення діяльності неурядових організацій, що потребує і вдосконалення відповідної законодавчої бази i ухвалення на законодавчому рівні законів про непідприємницькі (неприбуткові) організації, про волонтерську діяльність;

- непрозорий характер проведення конкурсів із залучення бюджетних коштів для фінансування важливих суспільних, зокрема й безпекових проектів, що реалізуються за участю НДІ (в Україні пряме державне фінансування структур громадянського суспільства досягає 2\% - $3 \%$ порівняно з $30-40 \%$ у країнах Центральної Європи);

- відсутність паритетного розвитку держави, громадського й приватного секторів, коли держава вирішує ті проблеми, які не можуть розв'язати недержавні інституції. До цього часу залишається недосконалим законодавче врегулювання у сферах надання благодійної допомоги, правової допомоги громадянам (не знайшла свого відповідного відображення в процесуальних кодексах України) тощо [9, с. 148 ].

Висновки. Підсумовуючи результати проведеного дослідження, можемо виділити ряд факторів, реалізація яких буде значно сприяти поліпшенню національної та гуманітарної безпеки України:

- реалізація конституційних положень про розвиток України як демократичної, правової, соціальної держави;

• реальний, а не декларований поділ гілок влади, чіткіше визначення повноважень кожної гілки влади;

- консенсус населення й влади по основних питаннях внутрішньої політики; 
• висока легітимність й ефективність існуючого політичного режиму;

- відсутність глибокого соціального розшарування суспільства;

- наявність численного «середнього класу» як головної соціальної основи суспільства й держави;

- захист інформаційного простору держави, протидія інформаційним та кібератакам з боку Російської Федерації;

- формування гуманітарного простору Української держави;

- підтримка розвитку культурних індустрій, збереження й популяризація історико-культурної спадщини.

Загалом широка проблематика громадянського суспільства повинна активно відображатися в ключових доктринально-політичних документах та законах України, які б визначали основні параметри безпеки, форми й механізми іiі забезпечення, адекватні сучасним загрозам та викликам та сприяли успішному реформуванню таких важливих сферах суспільної життєдіяльності як внутрішньополітична, гуманітарна, соціальна, духовна, інформаційнокомунікативна, екологічна та інші

\section{Лimepamypa:}

1.Характеристика громадських формувань як інститутів громадянського суспільства. URL: https://minjust.gov.ua/m/str_33565

2.Закон України «Про культуру». URL: https://zakon.rada.gov.ua/laws/show/2778-17

3.Закон України «Про освіту». URL: https://zakon.rada.gov.ua/laws/show/2145-19\#Text

4.Мерніков Г. Формування політики України у сфері національної безпеки: контроль процесу громадськими інститутами. URL: www.niss.gov.ua/Monitor/januar2009/12.htm.

5.Закон України Про національну безпеку України. URL: https://zakon.rada.gov.ua/laws/ show/2469-19\#Text

6.Свген Марчук: Рушієм політики $є$ не ідеологія, a принципи. URL: https://day.kyiv.ua/uk/article/podrobici/ievgen-marchuk-rushiiem-politiki-ie-ne-ideologiya-principi

7.Про демократичний цивільний контроль над Воєнною організацією i правоохоронними органами держави URL: https://zakon.rada.gov.ua/laws/show/975-15\#Text

8.Гончаренко О., Джангужин Р., Лисицин Е. Громадянський контроль і система національної безпеки / О. Гончаренко, Р. Джангужин, Е. Лисицин // Нац. безпека України. 2003. - № 1. - С. 39-46.

9.Левенець С. В. Дисертаційне дослідження на здобуття наукового ступеня кандидата політичних наук на тему: «Механізми впливу соціально-професійних груп на політику національної безпеки держави». К. НІСД. 2017. 189 с.

\section{References:}

1.Kharakterystyka hromadskykh formuvan yak instytutiv hromadianskoho suspilstva. [Characteristics of public formations as institutions of civil society]. URL: https://minjust.gov.ua/m/str_33565 [in Ukrainian].

2.Zakon Ukrainy «Pro kulturu». [Law of Ukraine "On Culture"]. (n.d.). zakon.rada.gov.ua. Retrieved from URL: https://zakon.rada.gov.ua/laws/show/2778-17 [in Ukrainian].

3.Zakon Ukrainy «Pro osvitu». [Law of Ukraine "On Education"]. (n.d.). zakon.rada.gov.ua. Retrieved from https://zakon.rada.gov.ua/laws/show/2145-19\#Text [in Ukrainian]. 
4.Mernikov H. Formuvannia polityky Ukrainy u sferi natsionalnoi bezpeky: kontrol protsesu hromadskymy instytutamy. [ Formation of Ukraine's policy in the field of national security: control of the process by public institutions] www.niss.gov.ua/Monitor/januar2009/12.htm [in Ukrainian].

5.Zakon Ukrainy Pro natsionalnu bezpeku Ukrainy. [Law of Ukraine On National Security of Ukraine] (n.d.). zakon.rada.gov.ua. Retrieved from https://zakon.rada.gov.ua/laws/show/246919\#Text [in Ukrainian].

6.Ievhen Marchuk: Rushiiem polityky ye ne ideolohiia, a pryntsypy. [The driving force of politics is not ideology, but principles]. Retrieved from https://day.kyiv.ua/uk/article/podrobici/ ievgen-marchuk-rushiiem-politiki-ie-ne-ideologiya-principi] [in Ukrainian].

7.Pro demokratychnyi tsyvilnyi kontrol nad Voiennoiu orhanizatsiieiu i pravookhoronnymy orhanamy derzhavy [On democratic civilian control over the military organization and law enforcement agencies of the state] (n.d.). zakon.rada.gov.ua. Retrieved from URL: https://zakon.rada.gov.ua/laws/show/975-15\#Text [in Ukrainian].

8.Honcharenko O., Dzhanhuzhyn R., Lysytsyn E. (2003). Hromadianskyi kontrol i systema natsionalnoi bezpeky [Civic control and system of national security]. Natsionalna bezpeka Ukrainy, № 1, S. 39-46 [in Ukrainian].

9.Levenets S. V. (2017). Dysertatsiine doslidzhennia na zdobuttia naukovoho stupenia kandydata politychnykh nauk na temu: «Mekhanizmy vplyvu cotsialno-profesiinykh hrup na polityku natsionalnoi bezpeky derzhavy». [Dissertation research for the degree of candidate of political science on the topic: "Mechanisms of influence of socio-professional groups on the national security policy of the state.]" K. NISD. 2017 [in Ukrainian]. 